\title{
JOB SATISFACTION AND JOB PERFORMANCE DALAM KONTEKS KOMUNIKASI ORGANISASI
}

\author{
Wulan Purnama Sari
}

Fakultas Ilmu Komunikasi, Universitas Tarumanagara, Jakarta

Email: wulanp@fikom.untar.ac.id

Masuk : 18-03-2020, revisi: 09-04-2020, diterima untuk diterbitkan : 09-04-2020

\begin{abstract}
ABSTRAK
Kepuasan kerja merupakan salah satu faktor yang mempengaruhi kinerja, hal ini sesuai dengan hasil penelitian sebelumnya yang juga menunjukkan bahwa kepuasan karyawan mempengaruhi kinerjanya. Penelitian ini dilakukan dengan tujuan untuk menggambarkan kepuasan kerja dalam meningkatkan kinerja pekerjaan, terutama di divisi pemasaran. Divisi marketing menjadi pilihan penulis karena merupakan garda terdepan perusahaan dalam mencapai profit dan memenuhi tujuan perusahaan, divisi marketing juga merupakan divisi yang berhubungan secara langsung dengan klien. Penelitian ini dilakukan di salah satu perusahaan distributor elektronik terkemuka di Indonesia. Metode penelitian menggunakan pendekatan kualitatif dengan metode studi kasus, dengan cara memperoleh data melalui wawancara dengan sumber terkait. Hasil penelitian menunjukkan bahwa ada banyak kendala dalam perusahaan yang menghambat kinerja karyawan, sehingga karyawan merasa kurang puas dan menyebabkan tingkat turnover yang tinggi dalam perusahaan tersebut. Salah satu faktor yang menjadi kendala adalah masalah komunikasi topdown atau antara atasan dan bawahan yang tidak berjalan dengan lancar, sehingga seringkali menimbulkan miskomunuikasi yang berujung pada kinerja dan kepuasaan karyawan. Secara keseluruhan terdapat beberapa faktor yang menjadi penyebab dari kurangnya kepuasaan karyawan sehingga berdampak pada kinerja, yaitu: sistem reward, ketidakjelasan job desk, tingkat stress yang tinggi membuat karyawan tidak nyaman.
\end{abstract}

Kata Kunci: job saticfaction, job performance, komunikasi organisasi

\begin{abstract}
Job satisfaction is one of the factors that influence job performance, this is in accordance with the results of previous research which also shows that employee satisfaction affects its performance. This research was conducted with the aim of describing job satisfaction in improving job performance, especially in the marketing division. The marketing division is the author's choice because it is the company's front guard in achieving profits and meeting company goals, the marketing division is also a division that deals directly with clients. This research was conducted at one of the leading electronics distributor companies in Indonesia. The research method uses a qualitative approach with the case study method, by obtaining data through interviews with relevant sources. The results showed that there are many obstacles in the company that hinder employee performance, so employees feel less satisfied and cause a high turnover rate in the company. One factor that is an obstacle is the problem of topdown communication or between superiors and subordinates that do not run smoothly so that it often leads to miscommunication that results in employee satisfaction and performance. Overall several factors cause the lack of employee satisfaction so that it has an impact on performance, namely: reward systems, unclear job desk, highstress levels make employees uncomfortable.
\end{abstract}

Keyword: job saticfaction, job performance, organizational communication

\section{PENDAHULUAN}

\section{Latar Belakang}

Job satisfaction (kepuasan kerja) merupakan salah satu faktor yang mempengaruhi job performance (kinerja) sesuai dengan yang telah dibuktikan (Afianto \& Utami, 2017; Yuen, Loh, Zhou, \& Wong, 2018). Kedua faktor tersebut memiliki peran penting dalam berjalannya suatu perusahaan. Suatu perusahaan terdiri dari sumber daya manusia yang berperan sebagai pimpinan dan karyawan, dimana keduanya terlibat dalam proses komunikasi, baik komunikasi secara internal maupun eksernal, sehingga dapat dikatakan bahwa komunikasi merupakan bagian yang tidak terpisahkan dari keberlangsungan suatu perusahaan. Sementara, kepuasan kerja merupakan 
perasaan emosional yang menjadi cerminan dari perasaan karyawan terhadap pekerjaan dan segala sesuatu yang berhubungan dengan pekerjaan tersebut (Afianto \& Utami, 2017; Nur, 2013). Penelitian ini sendiri bertujuan untuk mendeskripsikan job satisfaction dalam meningkatkan job performance di sebuah perusahaan distributor elektronik terkemuka di Indonesia melalui sudut pandang komunikasi organisasi, karena komunikasi organisasi merupakan sesuatu yang tidak terlepas dari keberadaan suatu perusahaan. Ruang lingkup penelitian ini terbatas pada deskripsi job satisfaction dalam meningkatkan job performance hanya pada divisi marketing dalam perusahaaan tersebut. Divisi marketing menjadi pilihan penulis karena merupakan garda terdepan perusahaan dalam mencapai profit dan memenuhi tujuan perusahaan, divisi marketing juga merupakan divisi yang berhubungan secara langsung dengan klien.

Berdasarkan hasil wawancara awal, peneliti mendapatkan beberapa temuan yang dapat menyebabkan kendala atau pemasalahan dalam kaitannya dengan job satisfaction dan job performance, yaitu: system reward, job stress, job characteristic, dan dispositional affect. Pertama terkait dengan system reward terdapat empat permasalahan yang ditemui: (1) Gaji atau imbalan kerja yang diberikan kurang sesuai; (2) Kurangnya manfaat bagi kepentingan keluarga pekerja; (3) Kurang jelasnya masalah promosi pada perusahaan (Kenaikan jabatan); (4) Kurangnya pelatihan yang diberikan oleh perusahaan.

Kedua, terkait dengan job stress, yaitu: kurangnya pemenuhan tujuan hidup pekerja (work-life balance) yang membuat karyawan stress; kurangnya dukungan atau kerjasama dari rekan kerja ; kurangnya motivasi kerja; jam kerja dianggap kurang sesuai; suasana lingkungan kerja yang kurang sesuai. Ketiga terkait dengan job characteristic, yaitu: pekerjaan tidak sesuai dengan keterampilan; pekerjaan tidak teratur dan sulit di identifikasi (kurangnya peran job desk); otonomi atas tanggung jawab pekerjaan kurang; kurangnya penilaian dan kritik atas pekerjaan. Terakhir permasalahan terkait dengan dispositional affect, yaitu: pekerja kurang cocok atas pekerjaannya; kurangnya pengendalian atas pekerjaan yang diberikan; cenderung merasa lelah di tempat kerja (tekanan yang tinggi).

Berdasarkan permasalahan yang temukan diatas dapat dilihat bahwa komunikasi internal kurang berjalan dengan lancar, kemudian juga adanya permasalahan dalam pengelolaan sumber daya manusia atau manajemen sumber daya manusia. Dalam keberlangsungan organisasi faktor komunikasi dan manajemen sumber daya manusia memegang peranna yang penting. (Samsuni, 2017)

\section{Manajemen Sumber Daya Manusia}

Manajemen Sumber Daya Manusia adalah proses perencanaan, pengorganisasian, pelaksanaan dan pengontrolan terhadap sumber daya manusia dalam organisasi untuk mencapai tujuan secara efektif dan efesien. Manajemen Sumber Daya Manusia memiliki lingkup yang luas, salah satu pengertian dan batasan yang digunakan adalah manajemen sumber daya manusia, merupakan kebijakan dan praktik yang dibutuhkan oleh seseorang untuk menjalankan aspek sumber daya manusia dari posisi seorang manajer. (Samsuni, 2017)

Kunci dalam kegiatan manajemen sumber daya manusia ini, terbagi dalam: (1) kinerja karyawan, yang menunjukkan hasil kerja karyawan baik secara kualitas dan kuantitas, sesuai dengan job desk dan tanggung jawab masing-masing; (2) produktifitas karyawan, hasil keluaran dari kerja karyawan; (3) semangat kerja karyawan, kondisi karyawan dalam melakukan pekerjaannya setiap hari. 


\section{Job Performance}

Bernardin \& Russel (1998) memberikan definisi tentang kinerja sebagai catatan tentang hasilhasil yang diperoleh dari fungsi-fungsi pekerjaan tertentu atau kegiatan tertentu selama kurun waktu tertentu. Pengertian tersebut menunjuk pada bobot kemampuan individu di dalam memenuhi ketentuan-ketentuan yang ada di dalam pekerjaan itu. Pada umumnya, prestasi kerja diberi batasan sebagai kesuksesan seseorang di dalam melaksanakan suatu pekerjaan.

Pentingnya mempelajari kepuasan kerja (job satisfaction) dalam penelitian perilaku organisasi dikaitkan dengan korelasi positif dengan kinerja pekerjaan, yang pada akhirnya mendorong kinerja organisasi. Seorang karyawan yang sangat puas dengan pekerjaannya akan mengungguli rekannya yang tidak puas. Para sarjana menyarankan bahwa karyawan yang puas cenderung hadir di tempat kerja lebih sering (yaitu absensi rendah), membuat lebih sedikit kesalahan (yaitu kualitas), menjadi lebih produktif, dan memiliki niat yang lebih kuat untuk tetap di organisasi. Berdasarkan meta-analisis, telah dilaporkan bahwa kepuasan kerja memiliki pengaruh positif terhadap prestasi kerja. (Thai, Balasubramanyam, Yeoh, \& Norsofiana, 2013; Yuen et al., 2018)

\section{Job Satisfaction}

Kepuasan kerja (job satisfaction) merupakan perasaan emosional yang menyenangkan atau tidak menyenangkan tentang bagaimana para karyawan memandang pekerjaan mereka (Handoko, 2011). Kepuasan kerja pada dasarnya adalah perasaan yang bersifat individual. Setiap individu memiliki rasa kepuasan yang berbeda-beda sesuai dengan sistem nilai yang berlaku pada dirinya. Makin tinggi penilaian terhadap kegiatan dirasakan sesuai dengan keinginan individu, maka makin tinggi juga kepuasannya terhadap kegiatan tersebut. Jadi secara garis besar kepuasan kerja dapa diartikan sebagai hal yang menyenangkan atau yang tidak menyenangkan yang mana karyawan pandang dalam pekerjaannya.

Salah satu faktur yang mempengaruhi produktivitas adalah peningkatan dari kepuasan kerja (Wijono, 2010) jika tenaga kerja mempresepsikan bahwa usaha yang telah dikeluarkan dan hasil yang didapatkan dari usaha tersebut kedua-duanya dirasa adil dan pantas untuk dibuktikan dengan hasil kerja yang terbaik.

Hal serupa juga dikemukakan dalam teori keseimbangan (equity theory). Prinsip dari teori ini adalah bahwa orang akan merasa puas atau tidak puas, tergantung apakah ia merasakan adanya keseimbangan (equity) atau tidak terhadap suatu pekerjaan (Wexley, Kenneth, N dan Yukl, 2000). Menurut teori ini equity terdiri dari tiga elemen, yaitu:

a) Input yaitu segala sesuatu yang berharga yang dirasakan oleh karyawan sebagai sumbangan atas pekerjaannya.

b) Outcomes yaitu segala sesuatu yang berharga yang dirasakan oleh karyawan sebagai hasil dari pekerjaannya.

c) Comparison Persons yaitu Kepada atau dengan siapa karyawan membandingkan rasio input - outcomes yang dimilikinya. Comparisons Persons ini bisa berupa seseorang di perusahaan yang sama, atau ditempat lain, atau bisa pula dengan dirinya sendiri di waktu lampau.

Menurut teori ini, puas atau tidak puasnya karyawan merupakan hasil dari membandingkan antara input-outcome dirinya dengan perbandingan input-outcome karyawan lain (comparison person). Jadi jika perbandingan tersebut dirasakan seimbang (equity) maka karyawan tersebut akan merasa puas. Tetapi apabila terjadi tidak seimbang (inequity) dapat menyebabkan dua kemungkinan, yaitu over compensation inequity (ketidakseimbangan yang menguntungkan 
dirinya) dan sebaliknya, under compensation inequity (ketidak seimbangan yang menguntungkan karyawan lain yang menjadi pembanding atau comparison person). Berdasarkan pemahaman diatas maka dapat disimpulkan bahwa kepuasan bekerjaan adalah perasaan senang atau tidak senang atas suatu pekerjaan, dengan cara membandingkan apa yang diberikan dengan apa yang diterima (perbandingan input-outcome)

\section{METODE PENELITIAN}

Penelitian menggunakan pendekatan kualitatif dengan metode studi kasus. Studi kasus digunakan untuk memberikan pemahaman akan sesuatu yang menarik perhatian, proses sosial yang terjadi, peristiwa konkret, atau pengalaman orang yang menjadi latar dari sebuah kasus (Prihatsanti, Suryanto, \& Hendriani, 2018). Metode studi kasus dipilih karena penelitian ini berfokus pada job satisfaction dan job performance yang terjadi di divisi marketing pada suatu organisasi tertentu.

Subjek dalam penelitian ini adalah karyawan divisi marketing dari perusahaan distributor elektronik (PT. XYZ), penelitian ini sendiri memiliki tiga orang narasumber yang merupakan karyawan divisi marketing PT.XYZ, yang berikutnya disebut dengan narasumber 1, narasumber 2, dan narasumber 3. Sedangkan objek dari penelitian ini adalah job job satisfaction dan job performance. Data dalam penelitian ini diperoleh melalui wawancara dengan narasumber dan juga melalui hasil observasi.

\section{HASIL DAN PEMBAHASAN}

Berdasarkan hasil wawancara yang dilakukan diperoleh beberapa kendala yang ditemui terkait dengan kepuasaan kerja dan kinerja. Kendala tersebut berupa: peran HRD, sistem penghargaan, tingginya tingkat stres dalam pekerjaan, deskripsi pekerjaan, dan dispositional affect.

\section{Peran HRD}

Berdasarkan hasil wawancara awal diketahui bahwa karyawan, khsuusnya karyawan di divisi marketing memiliki harapan HRD dapat menjadi penengah antara perusahaan dan karyawan guna mewujudkan kesejaterahan karyawan. Secara khusus harapan marketing PT. XYZ terhadap HRD adalah agar HRD berusaha meningkatkan mutu karyawan, potensi karyawan, sampai dengan peningkatan taraf hidup karyawan.

Marketing PT. XYZ kurang merasakan peran HRD yang mereka harapkan. Bahkan mereka menilai HRD kurang berkompetensi pada bidangnya, dapat dilihat dari kebijakan yang kurang sesuai dari sudut pandang para marketing. Maka masalah yang ada dapat disimpulkan peran HRD tidaklah sesuai dengan harapan para marketing, kebijakan-kebijakan dianggap berat bagi karyawan, sampai dengan mempertanyakan kompetensi HRD BIT. berikut adalah kutipan wawancara dengan narasumber 3:

"Menurut saya sangat jauh dari kata baik... menariknya diperusahaan ini divisi HRD dianggap sebagai kepala atau bisa dibilang management paling tinggi, tetapi setiap keputasan yang dibuat menurut saya hanya mementingkan kepentingan perusahaan dan sangat tajam kepada karyawan"

\section{Reward (Penghargaan)}

Tabel 1. Sistem Reward Terkat Gaji

\begin{tabular}{l} 
Hal : Kesesuaian gaji atau imbalan kerja \\
\hline Kolom Tanggapan Narsum 1
\end{tabular}


sih gajinya.. jika dibandingkan dengan teman saya yang lain

cukup oke lah.."

Dari wawancara para narasumber dapat dikatakan bahwa gaji yang merupakan imbalan kerja seorang karyawan, bagi marketing jika disesuaikan dengan pekerjaan maka gaji yang didapatkan dianggap kurang sesuai. Seringkali mengenai gaji atau imbalan kerja mereka bandingkan dengan lingkungan sosial yang ada, jika ditimbang lebih rendah maka cenderung akan dianggap gaji kurang sesuai. Tetapi dari wawancara tersebut narsum 1 mengindikasikan adanya sedikit kepuasan terhadap gaji, salah satu faktor yang mempengaruhi indikasi tersebut adalah status karyawan yang merupakan perkerja awal atau fresh graduate jadi dianggap harapan yang diterima lebih kecil dibandingkan dengan marketing dengan beberapa tahun pengalaman. Maka dapat disimpulkan bahwa adanya masalah mengenai sistem penggajian bagi mereka yang sudah memiliki pengalaman lebih, atau dapat dikatakan kurangn ya peningkatan gaji bagi mereka yang sudah berpengalaman lebih banyak.

Tabel 2. Sistem Reward Terkait Tunjangan bagi Keluarga Karyawan

\section{Hal : Manfaat karyawan bagi kepentingan keluarga}

\section{Kolom Tanggapan Narsum 1 Kolom Tanggapan Narsum 2 Kolom Tanggapan Narsum 3}

Menurut saudara apakah bekerja disini memiliki manfaat bagi keluarga?

\begin{tabular}{|c|c|c|}
\hline $\begin{array}{l}\text { "Manfaat seperti apa ya? } \\
\text { Kontribusi apa, mempersulit } \\
\text { malah iyah.." }\end{array}$ & $\begin{array}{l}\text { "Apa dahulu yang dimaksud } \\
\text { manfaat? Jika untuk menafkahi } \\
\text { keluarga, saya jawab cukup.. } \\
\text { tetapi tidak lebih.." }\end{array}$ & $\begin{array}{l}\text { "hmm.. menurut saya tidak } \\
\text { ada, kebetulan istri saya } \\
\text { bekerja di Bank X yang } \\
\text { merupakan salah } \\
\text { perusahaan besar di Indonesia.. } \\
\text { disana banyak manfaat baik } \\
\text { tunjangan dan kebijakan yang } \\
\text { diberikan kepada karyawan } \\
\text { demi kepentingan keluarga } \\
\text { juga.. seperti biaya kelahiran, } \\
\text { program cicilan rumah dengan } \\
\text { bunga rendah, cuti bagi suami } \\
\text { saat istri melahirkan, dan } \\
\text { banyak lainnya. Maka jika } \\
\text { dibandingkan } \\
\text { perusahaan saya tentu tidak } \\
\text { ada manfaat yang dapat saya } \\
\text { bandingkan." }\end{array}$ \\
\hline
\end{tabular}

Manfaat yang dimaksudkan Manfaat yang dimaksudkan

disini adalah bagaimana disini dapat digambarkan

perusahaan memberikan bagaimana perusahaan

kontribusi langsung bagi memberikan kebijakan-

kepentingan keluarga, apakah kebijakan yang berguna bagi

anda merasakannya? keluarga saudara, apakah

bermanfaat bagi saudara?

Berdasarkan wawancara para narasumber, marketing merasa tidak ada manfaat yang berarti dari perusahaan untuk kepentingan keluarga mereka. Karyawan juga membandingkan manfaat yang mereka terima dari perusahaan dengan tawaran atau manfaat yang diberikan oleh perusahaan lain. Bahkan bagi karyawan yang belum lewat masa percobaan perusahaan dianggap mempersulit kepentingan keluarga yang harusnya mereka jalankan. Maka dapat diindikasikan adanya masalah perusahaan yang kurang mementingkan kepentingan karyawan terutama dari segi keluarga yang merupakan salah satu faktor penting bagi pekerja. 
Tabel 3. Sistem Reward Terkait Kejelasan Karir

\begin{tabular}{llll}
\hline Hal : Kejelasan Karir & & \\
\hline Kolom Tanggapan Narsum 1 & Kolom Tanggapan Narsum 2 & Kolom Tanggapan Narsum 3 \\
\hline bagaimanakah kejelasan karir pada perusahaan saudara? & \\
\hline "untuk karir saya masih kurang & "Karena ini perusahaan & "Tingkatan karir cukup jelas \\
pahan disini, standart dan & keluarga tentunya nepotisme & mulai dari salesman bisa \\
syarat seperti apa tidak ada & sangatlah tinggi disini, dapat & menjadi marketing bahkan \\
informasi yang diberikan sih.." & dikatakan kinerja dinomor & dapat menjadi kepala penjualan \\
& duakan.." & setelah itu dapat menjadi \\
& & kepala cabang ataupun \\
& & manager divisi.. tetapi \\
& & ketentuannya menurut saya \\
\end{tabular}

Berdasarkan hasil wawancara, para marketing merasa informasi mengenai jenjang karir masih sangat kurang, Seperti yang diketahui karir merupakan penghargaan yang sangat dinantikan oleh setiap karyawan, tanpa kejelas karis karyawan seakan tidak termotivasi untuk melakukan pekerja lebih baik. Secara gambaran tingkatan struktur perusahaan cukup jelas menginformasikannya, tetapi secara pencapaiannya masih banyak menjadi pertanyaan. Bahkan disampaikan karena sifat perusahaan yang masih merupakan perusahaan tertutup atau perusahaan keluarga, maka tingkat nepotisme untuk karir sangat tinggi dinilai oleh karyawan. Semua promosi yang ada berdasarkan keputusan tanpa alasan dan penilaian yang jelas dari top management, hal ini yang menimbulkan masalah pada perusahaan yakni kejelasan karir, penilaian dan pencapaian.

Tabel 4. Sistem Reward Terkait Pelatihan Kerja bagi karyawan

\begin{tabular}{|c|c|c|}
\hline \multicolumn{3}{|c|}{ Hal : Pelatihan Kerja bagi karyawan } \\
\hline Kolom Tanggapan Narsum 1 & Kolom Tanggapan Narsum 2 & Kolom Tanggapan Narsum 3 \\
\hline \multicolumn{3}{|c|}{ Menurut saudara apakah pelatihan kerja penting? } \\
\hline $\begin{array}{l}\text { "Pentinglah, untuk menambah } \\
\text { kemampuan karyawan.. kan } \\
\text { kalo karyawan makin terampil } \\
\text { makin bagus kerjanya.." }\end{array}$ & $\begin{array}{l}\text { "Penting menurut saya, zaman } \\
\text { terus berkembang sebagai } \\
\text { contoh online market yang } \\
\text { terus berkembang tentunya } \\
\text { maka perlulah pelatihan } \\
\text { pelatihan kompetensi agar para } \\
\text { marketing tetap up to date." }\end{array}$ & $\begin{array}{l}\text { "Penting dong.. seperti yang } \\
\text { kita ketahui seringkali divisi } \\
\text { accounting sinis terhadap kita } \\
\text { karena tidak terlalu paham } \\
\text { tentang pajak ketika kita ingin } \\
\text { melakukan promosi.. } \\
\text { seharusnyakan hal seperti ini } \\
\text { tidak terjadi kita mendapatkan } \\
\text { pelatihan..." }\end{array}$ \\
\hline \multicolumn{3}{|c|}{ Apakah menurut anda pelatihan diperusahaan saudara sudah berjalan dengan baik? } \\
\hline $\begin{array}{l}\text { "Mana ada pelatihan disini, } \\
\text { produk knowledge aja disuruh } \\
\text { liat brosur sama website.. lalu } \\
\text { tanyakan sendiri ke pabrik atau } \\
\text { ruko service.." }\end{array}$ & $\begin{array}{l}\text { "lebih tepatnya belum ada } \\
\text { pelatihan keterampilan secara } \\
\text { khusus, hanya ada pelatihan } \\
\text { seperti produk knowledge.. } \\
\text { itupun jarang dilakukan.. disini } \\
\text { kita dituntut belajar sendiri.." }\end{array}$ & $\begin{array}{l}\text { "hahahaha... seperti yang kamu } \\
\text { ketahui jugalahh.. tentunya } \\
\text { tidak berjalan dengan baik." }\end{array}$ \\
\hline
\end{tabular}

Berdasarkan hasil wawancara dengan para narasumber, para marketing merasa pentingnya pelatihan kerja atau keterampilam bagi mereka. Tetapi perusahaan sama sekali tidak memberikan pelatihan, bahkan hal mendasarkan seperti product knowledge dapat dinilai tidak diberikan dengan baik atau seharusnya. Marketing merasa segala keterampilan kerja harus mereka dapatkan dari pembelajaran sendiri tanpa pelatihan, bahkan arahan dari atasan dianggap kurang. 
Atasan yang seharusnya memberikan coaching dan mentoring mengabaikan peran tersebut, sehinggal masalah ini menyebabkan salah satu faktor yang mempengaruhi kepuasan kerja marketing. Penulis menyimpulkan bahwa banyaknya masalah sistem penghargaan (Reward) yang harusnya segera diperbaiki dan ditanggani, karena faktor tersebut mempengaruhi kepuasan kerja karyawan (Job satisfaction) yang berujung pada kurangnya produktifitas penjualan mengingat peran marketing pada penjualan dan keuntungan perusahaan.

\section{Job Stress}

Tingkat stres pekerjaan merupakan salah satu faktor yang mepengaruhi kepuasan kerja karyawan, berdasarkan wawancara dengan para marketing berpendapat bahwa pekerjaan mereka tidak dapat memenuhi work-life balance. Tetapi kecil kemungkinan menimbulkan stres kerja, salah penyebabnya persepsi mengenai bekerja itu sendiri. Persepsi tentang perkerjaan membuat karyawan menilai arti sebuah pekerjaan itu tersendiri, bagi orang yang beranggapan work-life balance tidaklah menjadi yang utama maka mereka dapat terhidar dari stres kerja ketika hal tersebut tidak terpenuhi.

Berdasarkan hasil wawancara, dapat disimpulkan bahwa dukungan dan kerjasama antara karyawan atau rekan kerja tidak berjalan dengan baik. Mulai dari peran seorang atasan yang seharusnya memberikan supervisi pada bawahan, gagal dilakukan sang manager kepada marketing. Bahkan bukan dukungan bantuannya diberikan tetapi beban ditekankan kembali kepada marketing, sehingga pada perusahaan ini seluruh beban tanggung jawab menjadi terkumpul pada marketing. Pada wawancara tersebut dapat dilihat gambaran suasana kerja salesman yang bertoleransi tinggi menyebabkan para salesman meremehkan atau tidak mempedulikan perkerjaan tanggung jawab mereka.

Divisi lain juga sulit bekerja sama, dukungan atau pertolongan yang terkadang diminta oleh marketing dianggap sebagai sebuah beban tugas yang tidak menyenangkan bagi divisi lain. Jika disimpulkan dari wawancara akan terlihat perubahan sikap yang kurang menyenangkan dari divisi lain ketika permohonan bantuan atau kerjasama disampaikan oleh marketing. Masalah menjadi sangat besar dan tingkat stres sangat tinggi karena indikasi ini, bahkan marketing dapat berpendapat mencari pekerjaan yang lebih baik untuk menangani stres kerja ini.

Mengenai motivasi menjadi salah satu masalah yang harus diselesaikan, karena motivasi kerja sangat penting guna meningkatkan produktivitas karyawan. Dukungan motivasi kerja tidak diterima oleh marketing bahkan mereka merasa management hanya memberikan tekanantekanan tanpa motivasi penyelesaian. Motivasi diri sendiri bagi keluarga menjadikan alasan tersendiri bagi para marketing agar tetap menjalankan tugasnya dengan baik dan bertahan berkerja pada perusahaan, tetapi hal ini akan menjadi masalah baru jika marketing menerima tawaran lain ditempat lain.

Mengenai kesesuaian jadwal kerja yang merupakan salah satu indikasi penyebab terjadinya stres kerja tidak dirasakan oleh marketing. Mereka mayoritas merasa jadwal kerja cukup sesuai, salah satu faktornya adalah tidak adanya tekanan dari atasan atau management yang mengharuskan marketing untuk mengikuti lembur. Bahkan kebijakan perusahaan yang sangat ketat untuk perihal lembur (kerja tambahan) membetuk budaya kerja yang tidak terbiasa atau menjadi pantangan untuk melakukan lembur kerja. 
Suasana kerja yang dirasakan setiap tim cukup berbeda, tetapi salah satu faktor penyebab suasana yang kurang nyaman adalah faktor atasan. Konflik dengan atasan atau konflik antara top management seringkali menjadikan suasana tidak nyaman, dan mengorbankan marketing sebagai penyambung pekerjaan antara tim satu dengan yang lainnya. Masalah suasana lingkungan tidak berdapak secara langsung kepada marketing tetapi menciptakan masalah lain yang cukup serius pada divisi sales, yaitu: salesman menjadi terlalu nyaman dengan lingkungan sehingga kinerja salesman dinilai kurang memuaskan.

Kesimpulannya masalah job stress diindikasikan cukup serius karena marketing bahkan sudah memiliki pilihan atau pendapat mereka ingin mencari atua menganti pekerjaan. Supervisi yang kurang dari atas, tekanan yang tinggi, motivasi yang kurang, menyebabkan tingkat stres kerja cukup tinggi. Ditambah lagi dengan konflik dengan atasan yang mempersulit posisi marketing diperusahaan, bahkan suasana yang nyaman antara marketing dan salesman menimbulkan kurangnya tanggung jawab perkerjaan pada salesman. Masalah job stres ini akan mempengaruhi kepuasan kerja bahkan memicu pada turn over karyawan.

\section{Job characteristics}

Tabel 5. Kejelasan job desk

\begin{tabular}{lll}
\hline Hal : Kejelasan job desk & & \\
\hline Kolom Tanggapan Narsum 1 & Kolom Tanggapan Narsum 2 & Kolom Tanggapan Narsum 3 \\
\hline Apakah jobdesk jelas diberikan? & & \\
\hline "Jobdesk yah.. hmm.. disini "Disinimah tidak ada jobdesk & "tidak jelas sih, tidak tertuang \\
sesuai apa yang diajarkan saja pasti, apa yang diperitah secara tertulis.. bahkan bisa \\
sih sama apa yang disuruh \\
boss.." & $\begin{array}{l}\text { manager itulah yang kita dibilang kerja serabutan apa } \\
\text { lakukan." }\end{array}$ & $\begin{array}{l}\text { yang diperintahkan oleh } \\
\text { atasan.." }\end{array}$ \\
\hline
\end{tabular}

Masalah kurang jelasnya job desk menjadikan pekerjaan kurang teratur dan sulit diindentifikasi, hal ini dapat memperlambat pekerjaan marketing karena mereka harus mengindentifikasi masalah terlebih dahulu untuk penyelesaiannya. Seharusnya manager dapat mengambarkan secara jelas tugas-tugas apa saja yang harus menjadi tanggung jawab marketing, bukan memberikan tugas dengan momentum tertentu.

Keputusan yang harus dihasilkan oleh top management menyebabkan lambatnya penyelesaian tugas atau masalah yang dihadapi, tentunya dari segi efisiensi kerja sentralisasi tersebut sangatlah bertentangan. Sedangkan tuntutan para marketing cukup tinggi untuk kecepatan menyelesaikan masalah, mengingat banyaknya tugas yang harus dipertanggung jawabkan. Oleh karena itu masalah ini akan menyulitkan marketing yang berpengaruh kepada rasa Job Satisfaction (Kepuasan kerja) Marketing.

Penilaian dan masukan untuk peningkatan merupakan hal yang penting bagi karyawan untuk melakukan koreksi atas perkerjaan yang dilakukan. Tentunya selain untu memperbaiki kesalahan, hal ini juga dapat digunakan sebagai cara meningkatkan kinerja dengan cara meningkatkan efisiensi kerja. Penulis berpendapat dari hasil wawancara ini feedback hanya berupa teguran, tetapi bukan solusi yang membangun.

Berdasarkan hasil wawancara tersebut, penulis menyimpulkan bahwa masalah karakteristik kerja harus diperbaiki terutama dalam indikasi kejelasan job desk dan penyerahan otonomi. Karena sesuai dengan Yuen et al., (2018) karakteristik pekerjaan merupakan salah satu faktor yang mempengaruhi kepuasan kerja yang akan berujung pada meningkatnya kinerja atau produktivitas. 


\section{Dispositional affect}

Disposisi yang tercipta cenderung bersifat negatif, hal tersebut mengakibatkan ketidak cocokan pekerja dengan pekerjaan itu sendiri. Walaupun ada faktor positive seperti motivasi keluarga dan lingkungan pertemanan yang terbentuk dengan baik, tetapi secara menyeluruh masih belum dapat meningkatkan disposisi yang positif bagi karyawan. Maka masih dapat dikatankan bahwa mengenai perasaan negatif terhadap kecocokan kerja menjadi salah satu msalah yang harus diselesaikan guna meningkatkan kepuasan kerja (Job satisfaction).

Kendali atas pekerjaan pada kasus ini dipengaruhi oleh rekan kerja, menurut narasumber tidak ada hasil wawancara yang menggambarkan kurangnya kompentensi marketing pada pekerjaannya. Tetapi mengenai kompetensi masih tidak dapat dibuktikan karena tidak ada penilai secara khusus dengan indikator yang jelas dan ditetapkan atas dasar job desk masingmasing. Maka masalah pengendalian pekerjaan harus menjadi perhatian khusus baik dari sisi kompetensi maupun rekan kerja seperti intervensi atasan dan kelalaian bawahan.

Tabel 6. Dispositional affect Terkait Loyalitas kepada perusahaan

\begin{tabular}{|c|c|c|}
\hline \multicolumn{3}{|c|}{ Hal : Loyalitas kepada perusahaan } \\
\hline Kolom Tanggapan Narsum 1 & Kolom Tanggapan Narsum 2 & Kolom Tanggapan Narsum 3 \\
\hline \multicolumn{3}{|c|}{ Apakah anda lelah dengan perkerjaan anda? } \\
\hline $\begin{array}{l}\text { "tidaklah koh dibawa santai } \\
\text { saja.. haha" }\end{array}$ & "Lelah sama bosnya saja sih." & "Sangat !! hahaha.." \\
\hline \multicolumn{3}{|c|}{ Apakah saudara akan tetap loyal pada perusahaan? } \\
\hline $\begin{array}{l}\text { "tidak ada benefitnya, jika ada } \\
\text { tawaran yang lebih baik } \\
\text { kenapa tidak.." }\end{array}$ & $\begin{array}{l}\text { "hmm.. kalo saya sih } \\
\text { tergantung yah.. } \text { tergantung } \\
\text { bagaimana kedepannya, jika } \\
\text { semakian besar tekanan tetapi } \\
\text { pendapat tidak sebanding pasti } \\
\text { tidak loyal.." }\end{array}$ & $\begin{array}{l}\text { "Sepertinya sulit deh untuk } \\
\text { loyal, karena timbal balik } \\
\text { perusahaan tidak ada.. } \\
\text { Sepertinya saya akan mencari } \\
\text { yang baru.." }\end{array}$ \\
\hline
\end{tabular}

Dari hasil wawancara marketing cenderung lelah dengan pekerjaannya, salah satu faktornya adalah tekanan dari atasan. Hal mengarah pada kurangnya loyalitas dari pekerja, ditambah lagi marketing tidak merasakan benefit atau timbal balik yang sepadan dari apa yang mereka kerjakan. Maka mereka cenderung memilih tawaran lain jika ditawarkan ataupun mencari pekerjaan baru, tentunya hal ini sangat merugikan perusahaan karena pasti membutuhkan penyesuaian kembali jika posisi marketing digantikan oleh orang lain.

\section{Job Satisfaction}

Berdasakan penjelesan yang telah dituliskan diatas, maka pertanyaan berikutnya adalah bagaimana kepuasan kerja yang dimiliki oleh karyawan divisi marketing PT. XYZ, hal ini dapat dilihat melalui tabel dibawah ini:

Tabel 7. Kepuasan Kerja

Hal : Menilai kepuasan Kerja

Kolom Tanggapan Narsum 1 Kolom Tanggapan Narsum 2 Kolom Tanggapan Narsum 3 apakah saudara merasa puas dengan pekerjaan anda sekarang?

"Dibilang puas tidak, yah tidak "Dibilang puas dapat dikatakan ada action nyatanya dari tidak, tetapi harus dijalani demi management.. bagaimana kita keluarga." mau puas.."

"hmm.. sejujurnya tidak puas, hahaha... Tekanan tinggi. tanggung jawab tinggi. mobilitas pekerjaan tinggi, sedangkan yang diterima saya rasa tidak sepadan." 
Berdasarkan hasil wawancara dapat kita lihat penilaian marketing terhadap perkerjaan itu sendiri dianggap tidak puas atau Job Disatisfaction. Berdasarkan Yuen et al., (2018) teruji bahwa kepuasan kerja atau Job satisfaction merupakan salah satu faktor yang mempengaruhi kinerja karyawan.

\section{KESIMPULAN DAN SARAN}

Berdasarkan hasil wawancara dapat disimpulakn bahwa kepuasan kerja (Job Satisfaction) yang kurang baik pada sales \& marketing department dipengaruhi oleh :

1) Sistem reward yang dianggap kurang sesuai atau membutuhkan peningkatan baik berupa pelatihan, gaji, maupun insentif kerja

2) Tingkat stres kerja yang tinggi karena tingginya tekanan dan kurangnya motiasi kerja. Disertai tidak adanya arahan dari atasan dalam pekerjaan.

3) Job Desk dan otonom yang kurang baik, meyebabkan lambatnya penyelesaian masalah disertai dengan penilaian yang tidak terukur.

4) Disposisi negatif yang menyebabkan karyawan tidak nyama dengan pekerjaan, bahkan merasa tidak cocok dengan pekerjaan yang dijalani.

Saran yang dapat diberikan lebih diarahkan untuk meningkatkan kepuasan dan kinerja karyawan PT. XYZ, yaitu dengan mengembangkan sistem penghargaan bagi karyawan, sistem penghargaan dapat diberikan dalam ekstrinsik maupun intrisik.

\section{Ucapan Terima Kasih}

Penulis mengucapkan terima kasih kepada seluruh narasumber yang telah bersedia untuk bekerjasama selama proses penelitian ini berlangsung. Ucapan terima kasih juga diberikan kepada pada PT. XYZ atas kesediaannya untuk dijadikan subjek penelitian.

\section{REFERENSI}

Afianto, I. D., \& Utami, H. N. (2017). Pengaruh Disiplin Kerja Dan Komunikasi Organisasi Terhadap Kepuasan Kerja Dan Kinerja Karyawan (Studi pada Karyawan Divisi Marketing PT. Victory International Futures Kota Malang). Jurnal Administrasi Bisnis, 50(6), 58-67. Retrieved from http://administrasibisnis.studentjournal.ub.ac.id/index.php/jab/article/view/2081

Bernardin, J. H., \& Russel, J. A. (1998). Human Resource Management: An Experiental Approach. Singpore: McGraw Hill.

Handoko, T. H. (2011). Manajemen Personalia dan Sumber Daya Manusia. Pengantar Manajemen.

Nur, S. (2013). Konflik, Stres Kerja Dan Kepuasan Kerja Pengaruhnya Terhadap Kinerja Pegawai Pada Universitas Khairun Ternate. Jurnal EMBA: Jurnal Riset Ekonomi, Manajemen, Bisnis Dan Akuntansi, 1(3), 739-749. https://doi.org/10.35794/EMBA.V1I3.2238

Prihatsanti, U., Suryanto, S., \& Hendriani, W. (2018). Menggunakan Studi Kasus sebagai Metode Ilmiah dalam Psikologi. Buletin Psikologi, 26(2), 126-136. https://doi.org/10.22146/buletinpsikologi.38895

Samsuni, S. (2017). Manajemen Sumber Daya Manusia. Al-Falah: Jurnal Ilmiah Keislaman Dan Kemasyarakatan, 17(1), 113-124. Retrieved from http://ejurnal.staialfalahbjb.ac.id/index.php/alfalahjikk/article/view/19

Thai, V. V., Balasubramanyam, L., Yeoh, K. K. L., \& Norsofiana, S. (2013). Revisiting The Seafarer Shortage Problem: The Case of Singapore. Maritime Policy and Management, 40(1), 80-94. https://doi.org/10.1080/03088839.2012.744480 
Wexley, Kenneth, N dan Yukl, G. (2000). Perilaku Organisasi dan Psikologi Personalia, terjemahan Muh Shobaruddin. Rineka Cipta, Jakarta. https://doi.org/10.15294/jejak.v7i1.3596

Wijono, S. (2010). Psikologi Industri dan Organisasi: Dalam Suatu Bidang Gerak Psikologi Sumber Daya Manusia (Eds. 1). Jakarta: Prenadamedia Group.

Yuen, K. F., Loh, H. S., Zhou, Q., \& Wong, Y. D. (2018). Determinants of Job Satisfaction and Performance of Seafarers. Transportation Research Part A, 110, 1-12. https://doi.org/10.1016/j.tra.2018.02.006 